\title{
Field capture of Thyanta perditor with pheromone-baited traps
}

\author{
Raúl Alberto Laumann(1), Maria Carolina Blassioli Moraes ${ }^{(1)}$, Ashot Khrimian ${ }^{(2)}$ and Miguel Borges ${ }^{(1)}$
}

\begin{abstract}
(1)Embrapa Recursos Genéticos e Biotecnologia, Avenida W5 Norte (Final), CEP 70770-900 Brasília, DF, Brazil. E-mail: laumann@cenargen.embrapa.br, mcbmorae@cenargen.embrapa.br, mborges@cenargen.embrapa.br(2)United States Department of Agriculture, Agriculture Research Service, Beltsville Agricultural Research Center, Plant Sciences Institute, Invasive Insect Biocontrol and Behavior Laboratory, Baltimore Avenue, 10300, Beltsville, MD, 20705, USA. E-mail: ashot.khrimian@ars.usda.gov
\end{abstract}

\begin{abstract}
The objective of this work was to evaluate the field attractiveness of Thyanta perditor synthetic sex pheromone-baited traps, its attractivity to other stink bug species, and the response of T. perditor to a geometric isomer of the sex pheromone. Two-liter transparent plastic bottles traps were baited with rubber septa impregnated with the treatments: $1 \mathrm{mg}$ of methyl-(2E,4Z,6Z)-decatrienoate [(2E,4Z,6Z)-10:COOMe], the male sex pheromone of $T$. perditor; $1 \mathrm{mg}$ of $(2 E, 4 Z, 6 Z)-10$ :COOMe protected from sunlight in standard PVC plumbing pipe; $1 \mathrm{mg}$ of its geometric isomer [(2E,4E,6Z)-10:COOMe]; and traps with rubber septa impregnated with hexane (control). The experiment was carried out in field during the soybean reproductive stages. Traps were monitored weekly, and the captures were compared to the population density estimated by the sampling cloth and visual inspection monitoring techniques. Traps baited with the sex pheromone, protected or not, were more effective in capturing T. perditor than traps baited with the isomer or the hexane. Thyanta perditor sex pheromone showed cross-attraction to other stink bug species, such as Euschistus heros, Edessa meditabunda, Piezodorus guildinii and Nezara viridula. Pheromone-baited traps can be used in population monitoring and to identify the relative composition of stink bug guilds.
\end{abstract}

Index terms: cross-attraction, methyl-(2E,4Z,6Z)-decatrienoate, neotropical stink bugs, sex pheromone.

\section{Captura em campo de Thyanta perditor em armadilhas iscadas com feromônio}

\begin{abstract}
Resumo - O objetivo deste trabalho foi avaliar em campo a atratividade de armadilhas iscadas com o feromônio sexual sintético de Thyanta perditor, a possível atração de outras espécies de percevejos pelo feromônio sexual e a resposta de $T$. perditor ao isômero geométrico de seu feromônio sexual. Armadilhas construídas com garrafas plásticas de $2 \mathrm{~L}$ foram iscadas com septos de borracha impregnados com os tratamentos: $1 \mathrm{mg}$ de $(2 E, 4 Z, 6 Z)$-decatrienoato de metila [(2E,4Z,6Z)-10:COOMe], feromônio sexual de machos de $T$. perditor; $1 \mathrm{mg}$ de (2E,4Z,6Z)-10:COOMe protegido da luz solar com um tubo de PVC; $1 \mathrm{mg}$ do seu isômero geométrico [(2E,4E,6Z)-10:COOMe]; e septos de borracha impregnados com hexano (controle). O experimento foi conduzido em campo durante a fase reprodutiva da soja. As armadilhas foram monitoradas semanalmente, e as capturas comparadas com a densidade populacional estimada pelas técnicas de pano de batida e inspeção visual. As armadilhas iscadas com o feromônio sexual, protegido ou não, foram mais eficientes na captura de T. perditor que as armadilhas iscadas com o isômero ou com o hexano. Foi observada atração cruzada do feromônio sexual de T. perditor a outras espécies de percevejos, como Euschistus heros, Edessa meditabunda, Piezodorus guildinii e Nezara viridula. Armadilhas iscadas com o feromônio podem ser usadas no monitoramento populacional e na identificação da composição relativa de guildas de percevejos.
\end{abstract}

Termos para indexação: atração cruzada, $(2 E, 4 Z, 6 Z)$-decatrienoato de metila, percevejos neotropicais, feromônio sexual.

\section{Introduction}

Stink bugs are the most important soybean pest in Brazil and other countries of South America. These insects are found in guilds, and the species composition and abundance may vary between regions (Panizzi \& Côrrea-Ferreira, 1997). Thyanta perditor (Fabricius), which inhabits northern South America, Central
America and some states of the United States, such as Florida, Texas and Arizona (Panizzi et al., 2000), is a species of the soybean stink bug guild that may be found in other crops, such as wheat, rice, sorghum and sunflower, where it may feed on seeds (Malaguido \& Panizzi, 1998; Panizzi et al., 2000). In soybean, this species is as a secondary pest (Panizzi et al., 2000), and may reach high population levels in the central 
region of Brazil, especially in weed infested crop fields. Waldbauer (1977) also reports T. perditor as an important soybean pest in Colombia.

Stink bug control is done mainly with the application of synthetic insecticides, in most cases without a precise estimation of population density and control thresholds. As a result, more than $4 \times 10^{6} \mathrm{~L}$ of insecticides are used annually in Brazil to control this soybean pest (Corrêa-Ferreira \& Moscardi, 1996), and the indiscriminate use of insecticides has negative impacts on the economy, environment and human health.

The monitoring and control of stink bugs with semiochemicals has been proposed by several researchers as a more ecologically benign approach to their management (Borges et al., 1998a, 1998b; Millar et al., 2002; Cullen \& Zalom, 2005; Aldrich et al., 2007). In the last few years, technology using sex pheromone-baited traps for monitoring neotropical stink bug populations has been intensively researched. Technology for monitoring the neotropical brown stink bug (Euschistus heros) was developed, and pheromone-baited traps with its sex pheromone showed a positive relationship with field populations monitored with the shake cloth technique, which indicates it could be used to monitor seasonal fluctuations (Borges et al., 1998b; Pires et al., 2006; Borges et al., 2011).

With the isolation and identification of the T. perditor sexual pheromone (Moraes et al., 2005), a new tool for stink bug monitoring could become available. The $T$. perditor male-produced sex pheromone was identified as methyl-(2E,4Z,6Z)-decatrienoate $[(2 E, 4 Z, 6 Z)-10: \mathrm{COOMe}]$, the same compound identified in nearctic species of Thyanta; however, in the latter, the sexual pheromone is a blend that includes the decatrieonate and three sesquiterpenes $[(+)$ - $\alpha$-curcumene, (-)-zingiberene, and (-)- $\beta$-sesquiphellandrene)] (Millar, 1997; McBrien et al., 2002). Khrimian (2005) synthesized all the stereoisomers of methyl 2,4,6-decatrienoate, including $(2 E, 4 Z, 6 Z)-10$ :COOMe, making them available for field trials. The compound is photosensitive and can isomerize to produce a complex mixture (Khrimian et al., 2008); therefore, its stability in field conditions needs to be tested.

The geometric isomer of the $T$. perditor sex pheromone [(2E,4E,6Z)-10:COOMe] was identified (Sugie et al., 1996) as an aggregation pheromone of the brown-winged green bug, Plautia stali, which is native to Northeast Asia. It was found that $(2 E, 4 E, 6 Z)-10: C O O M e$ is attractive to at least two species of stink bugs that do not produce it. One is the brown marmorated stink bug, Halyomorpha halys, also native to Northeast Asia, which recently invaded the United States (Tada et al., 2001a, 2001b; Lee et al., 2002; Aldrich et al., 2007). The other is the green stink bug Chinavia hilaris (syn. Acrosternum hilare) (Aldrich et al., 2007), a species native to North America. The use of the isomer of the T. perditor synthetic sex pheromone can be a more economical and convenient monitoring tool, because it is more stable and accessible than the synthetic pheromone itself.

The objective of this work was to evaluate the field attractiveness of Thyanta perditor synthetic sex pheromone-baited traps, its attractivity to other stink bugs, and the response of $T$. perditor to a geometric isomer of the sex pheromone.

\section{Materials and Methods}

The T. perditor sex pheromone [(2E,4Z,6Z)$10: \mathrm{COOMe}]$ and its isomer [(2E,4E,6Z)- 10:COOMe] were synthesized as described by Khrimian (2005). Both compounds were $95 \%$ stereoisomerically pure, which was determined by nuclear magnetic resonance (NMR). Gray rubber septa were purchased from West Company, Kearney, NE, USA, and were extracted with acetone:hexane $(1: 1)$, in a Soxhlet extractor, prior to impregnation with pheromone solutions, as described by Khrimian et al. (2008). Septa were placed in a round-bottom one-neck Morton flask (Ace Glass, Inc., Vineland, NJ) and covered with a hexane solution ( $0.7 \mathrm{~mL}$ per septum), containing $1 \mathrm{mg}$ per septum of the tested compound. The flask was rotated on a closed rotary evaporator, without applying vacuum, for 1.5-2 $\mathrm{h}$ or until the liquid was completely absorbed into the septa. The septa were placed in a fume hood for $1 \mathrm{~h}$ to evaporate most of the remaining hexane, and subsequently used for field test.

In order to test the attraction of the synthetic pheromone $(2 E, 4 Z, 6 Z)-10$ :COOMe and the efficiency of the traps to capture $T$. perditor adults, a field test was performed in a soybean field (15 ha) in Brasília, Distrito Federal, Brazil $\left(15^{\circ} 47^{\prime} \mathrm{S}, 4^{\circ} 55^{\prime} \mathrm{W}\right)$. The experiment was carried out from $2 / 16 / 2007$ to $3 / 30 / 2007$, during the R3 and R8 soybean physiological stages 
(Fehr et al., 1971). The experimental field was surrounded by a county road to the south, a cornfield to the west, a left over sorghum crop (not harvested) to the east, and a natural riparian vegetation area to the north.

The traps used in the experiments were described in Borges et al. (1998b) and assembled from $2 \mathrm{~L}$ transparent plastic soft drink bottles. The traps had four holes at the top, each with a wire-mesh funnel to allow the entrance of insects and the dispersion of the pheromone plume. The septa with the synthetic pheromone were hung at the entrance opening level, inside the trap, with a wire. A plastic funnel was placed in the lower third of the bottle to retain the insects in the trap. The bottom of the bottle functioned as a collector of the insects which entered the trap (Borges et al., 1998b; Pires et al., 2006).

The treatments used in the experiment were: T1, traps baited with rubber septa impregnated with $1 \mathrm{mg}$ of (2E,4Z,6Z)-10:COOMe; T2, traps baited with rubber septa impregnated with $1 \mathrm{mg}$ of $(2 E, 4 Z, 6 Z)-10$ :COOMe, protected from direct sunlight exposure in standard PVC plumbing pipes of $65 \times 17 \mathrm{~mm}$ (internal diameter); T3, traps baited with rubber septa impregnated with $1 \mathrm{mg}$ of the synthetic pheromone isomer, (2E,4E,6Z)-10:COOMe; and T4, control, rubber septa impregnated with hexane. The rubber septa with $1 \mathrm{mg}$ of the different compounds were changed every week. The treatment protected from sunlight was tested, since the compound is photosensitive and can isomerize to produce a complex mixture, as observed by Khrimian et al. (2008).

The traps were randomly distributed in $400 \times 400 \mathrm{~m}$ squares, 20 to $30 \mathrm{~m}$ from the field borders. A total of 16 traps (four for each of the four treatments) were randomly distributed equidistantly, with $100 \mathrm{~m}$ between them. Traps were monitored once a week during the experiment. During each survey, insect number, species and sex were recorded. At each sampling date, two survey techniques were performed to estimate the population density (insects per square meter) and the species richness and abundance of the stink bugs in the guild. The shake cloth sampling technique (Herbert \& Harper, 1983) was used in 15 randomized complete sample units per week, distributed in the experimental area. The sample unit consisted of a $1 \mathrm{~m}$ long cloth placed under the plants. The plants were shaken and the number of insects that fell on the cloth was recorded.
The other technique used was the visual inspection and registration of the insects found on all plants (soybean and weeds) within 1 linear $\mathrm{m}$ of the culture. In both cases, the number of insects surveyed was converted to insects per square meter to obtain an estimation of the population density.

The total number of adults (females + males) and the number of male and female $T$. perditor captured in the traps with the different treatments throughout the experimental period were compared with generalized linear models (GLM) and analyses of deviance (Anodev), using Poisson errors and $\log$, as a link function. To compare the stink bug guilds sampled with the shake cloth technique and the pheromone-baited traps, insect richness and abundance were used to calculate the Shannon diversity index and the 95\% confidence interval, using the Bootstrap procedure. The diversity indexes were tested with the Shannon diversity $t$ test. The GLM and Anodev analyses were carried out using the $\mathrm{R}$ programming language ( $\mathrm{R}$ Development Core Team, 2008), and the diversity analyses were performed using the Past software (Hammer et al., 2001).

\section{Results and Discussion}

The mean number of $T$. perditor adults captured during the experiment were significantly different $(p<0.01)$ between treatments. The mean number of males did not show significant difference $(\mathrm{p}>0.05)$. In the traps baited with $(2 E, 4 Z, 6 Z)-10: C O O M e$, the female percentage was $96.67 \%$, whereas in the traps baited with the isomer $(2 E, 4 E, 6 Z)-10$ :COOMe it was $81.25 \%$ (Figure 1). The mean number of females captured in traps baited with the sex pheromone (protected or not from direct exposure to sunlight, T1 and T2) was higher than the mean number of females captured in traps baited with its isomer (T3) and in the control traps (T4) $(\mathrm{p}<0.05)$; T3 captured a significantly higher number of bugs than the control.

Survey dates affected the number of $T$. perditor females captured within treatments $(\mathrm{p}<0.01)$; however, there was no interaction between this factor and the pheromone use. The number of $T$. perditor females captured in the traps throughout the experimental period is shown in Figure 2. The number of T. perditor females captured in the pheromone-baited traps was higher than the number of insects caught by the shake cloth 
or visual inspection techniques, which are commonly used to estimate population density. This difference remained during the entire experimental period, except for the last week (Figure 3), when soybean reached physiological maturation, and the pheromone-baited traps showed a diminished efficiency. These results are consistent with those obtained by Borges et al. (2011) for the neotropical brown stink bug, E. heros, in soybean fields, and Cullen \& Zalom $(2000 ; 2005)$ for the nearctic Euschistus conspersus in tomato fields.

The efficiency of the pheromone-baited traps during soybean colonization by stink bugs (initial reproductive phenological stages) may be explained by the attracting migrating females theory (Aldrich, 1988; Borges et al., 2011). In the same period, due to the low populations of stink bugs, the shake cloth sampling technique was less efficient (Borges et al., 2011). Since the evaluations began in a more advanced soybean stage (R3) than the one surveyed by Borges et al. (2011), the effect on the migrating insects could not be checked. The performance of the pheromone-baited traps in the middle stages of the soybean cycle (R4 to R6) was very similar to the ones observed with E. heros (Borges

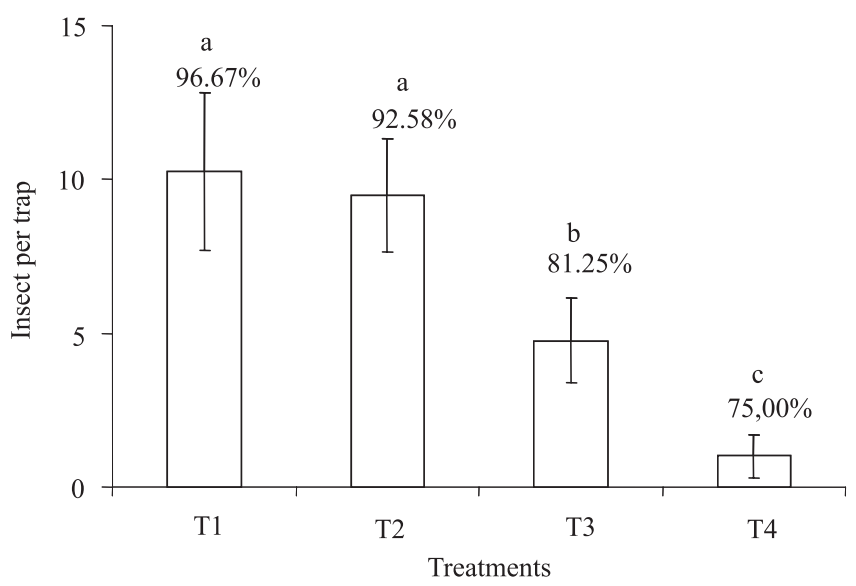

Figure 1. Thyanta perditor adults captured by pheromonebaited traps during the experimental period. Percentages are the proportion of females related to the total of insects captured by traps. Means \pm SD followed by the same letter do not differ by the analysis of deviance, at $1 \%$ probability. $\mathrm{T} 1$, traps baited with rubber septa impregnated with $1 \mathrm{mg}$ of $(2 E, 4 Z, 6 Z)-10: C O O M e . ~ T 2$, traps baited with rubber septa impregnated with $1 \mathrm{mg}$ of $(2 E, 4 Z, 6 Z)-10$ :COOMe, protected from direct sunlight. T3, traps baited with rubber septa impregnated with $1 \mathrm{mg}$ of $(2 E, 4 E, 6 Z)-10$ :COOMe. $\mathrm{T} 4$, traps with rubber septa impregnated with hexane (control). et al., 2011) and E. conspersus (Cullen \& Zalom, 2000; 2005), captured with their respective pheromones.

Although the traps became less effective in the R7 and R8 stages, they had a higher or similar efficiency to the sampling cloth or visual inspection sampling techniques. Borges et al. (2011) and Cullen \& Zalom (2005) showed that, in the final stages of crop growth, pheromone-baited traps lost their efficiency in comparison to the sampling cloth technique; probably a consequence of the migration of adults from the crops and the higher proportion of nymphs in the population (Panizzi \& Corrêa-Ferreira, 1997). The maintenance of the pheromone traps efficiency versus the other sampling techniques may be caused by the very low population density in the experimental area - less than one female per square meter.

This is the first known field demonstration of the attractiveness of the $T$. perditor sex pheromone $(2 E, 4 Z, 6 Z)-10: C O O M e$ to females of this species. The effectiveness of the traps baited with pheromone, protected or not from direct sunlight, indicates that, apparently, pheromone degradation during the one-

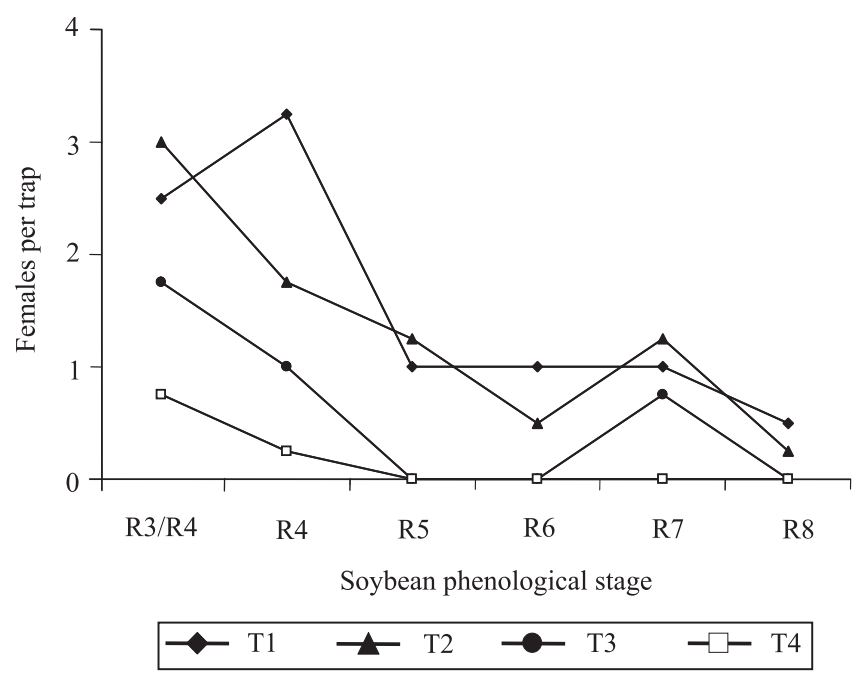

Figure 2. Thyanta perditor females captured per trap per week in the different treatments. T1, traps baited with rubber septa impregnated with $1 \mathrm{mg}$ of $(2 E, 4 Z, 6 Z)-10$ :COOMe. $\mathrm{T} 2$, traps baited with rubber septa impregnated with $1 \mathrm{mg}$ of $(2 E, 4 Z, 6 Z)-10: C O O M e$, protected from direct sunlight. T3, traps baited with rubber septa impregnated with $1 \mathrm{mg}$ of $(2 E, 4 E, 6 Z)-10$ :COOMe. T4, traps with rubber septa impregnated with hexane (control). The soybean stages R3, R4, R5, R6, R7, and R8 occurred at the following dates: $2 / 23,3 / 2,3 / 9,3 / 16,3 / 23$, and $3 / 30$, respectively. 
week period in which the treated septa were placed in the field did not harm field attractiveness. Isomerization products can be attractants themselves, which is supported by the fact that $(2 E, 4 E, 6 Z)-10$;COOMe was also attractive to $T$. perditor under these experimental conditions, since this compound can be formed by a photoinduced isomerization of $(2 E, 4 Z, 6 Z)-10$ :COOMe (Khrimian et al., 2008). Further investigation is needed to confirm whether $(2 E, 4 E, 6 Z)-10$ :COOMe has an intrinsic attractiveness to $T$. perditor or if it reversibly isomerizes to $(2 E, 4 Z, 6 Z)-10$ :COOMe in sunlight.

The pheromone-baited traps also captured other species of stink bugs (Figure 4). The Shannon diversity index was $1.08(0.31-1.30,95 \%$ confidence interval $\mathrm{CI}$ ) for the guild survey using the sampling cloth, and $0.65(0.51-0.95,95 \% \mathrm{CI})$ for the guild survey using pheromone traps. The guild composition estimated by the traps showed a higher dominance of $T$. perditor, but the diversity indexes compared by the Shannon diversity $\mathrm{t}$ test did not show significant differences $(p>0.05)$. The relative abundance of the others species was similar.

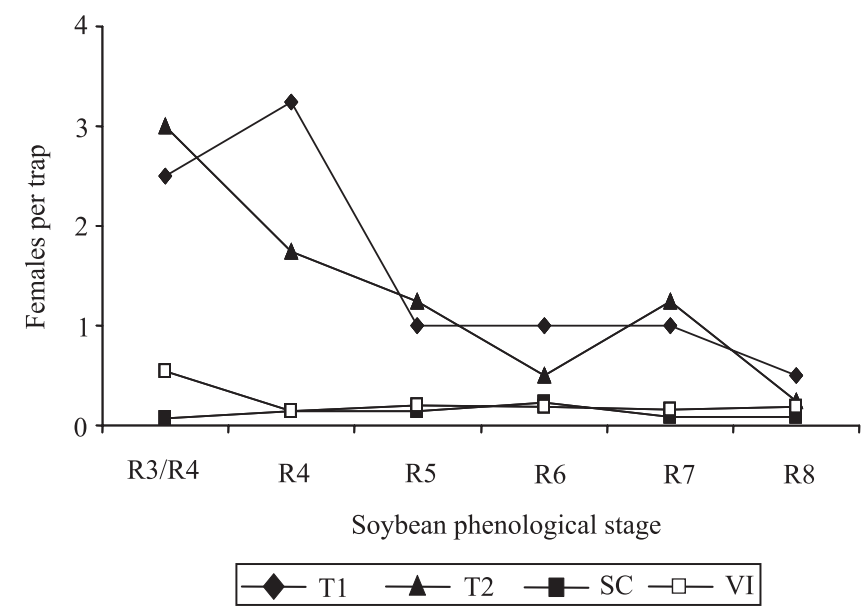

Figure 3. Comparison between Thyanta perditor captures per week per trap by pheromone-baited traps (T1 and T2) and female densities (female per square meter) estimated by sampling cloth or visual inspection techniques. T1, traps baited with rubber septa impregnated with $1 \mathrm{mg}$ of ( $2 E, 4 Z, 6 Z)-10$ :COOMe. T2, traps baited with rubber septa impregnated with $1 \mathrm{mg}$ of $(2 E, 4 Z, 6 Z)-10: \mathrm{COOMe}$, protected from direct sunlight. SC, T. perditor female density estimated by sampling cloth technique. VI, T. perditor female density estimated by visual inspection.
The sampling cloth technique is a reference method for stink bug monitoring and is considered a nonbiased method to estimate pest population (Kogan \& Pitre Junior, 1980). The similar performance of pheromone traps and sampling cloth is indicative that the pheromone-baited traps may be a tool for population density estimations and for identifying the relative composition of stink bug guilds, at least in guilds in which the baited traps use the pheromone of the dominant species.

Pheromone traps were able to capture others stink bug species (E. heros, Edessa meditabunda, Piezodorus guildinii and Dichelops furcatus) in a relative abundance, similar to the sampling cloth technique, which agrees with Pires et al. (2006) and Borges et al. (2011), who observed the cross-attraction of stink bugs to traps baited with the pheromone of E. heros.

There is still a debate on the reason for cross-attraction to sex pheromones of stink bugs. Endo et al. (2006) speculated that Piezodorus hybneri (Gmelin) could use the Riptortus clavatus (Thunberg) sex pheromone as a kairomone to search for food plants; similar speculations have been made by Tada et al. (2001a, 2001b). Aldrich et al. (2007) offered an alternative hypothesis to explain this behaviour, suggesting that it could be related to a mechanism of passive defence in stink bug aggregations. Eavesdropping on other pheromones apparently is a larger theme than initially thought of. Regardless of the reasons for cross-attraction, this phenomenon should be relevant to stink bug monitoring programs, since the use of a unique semiochemical to survey an entire stink bug guild has obvious economical and practical advantages.
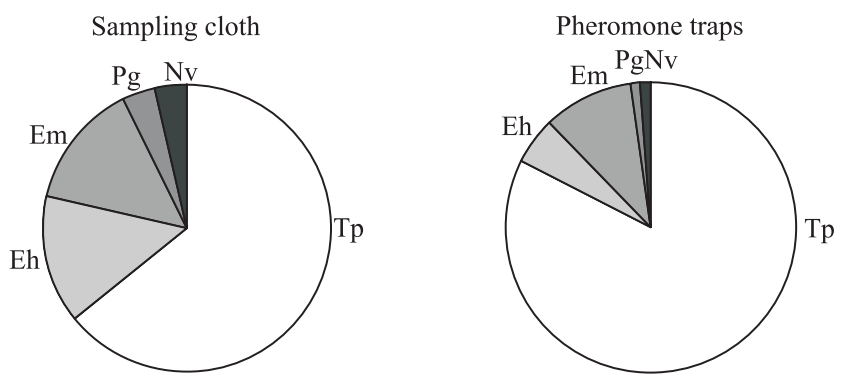

Figure 4. Relative abundance (\%) of the different species of stink bugs captured during the experimental period (six weeks) in pheromone-baited traps and sampling cloth. Tp, Thyanta perditor. Eh, Euschistus heros. Em, Edessa meditabunda. Pg, Piezodorus guildinii. Nv, Nezara viridula. 


\section{Conclusions}

1. The Thyanta perditor synthetic sex pheromone and its isomer are highly efficient female attractants, and can be used for population monitoring and to identify the relative composition of stink bug guilds in field conditions.

2. The T. perditor sex pheromone shows cross-attraction to other species of stink bugs.

\section{Acknowledgments}

To Helio M. dos Santos, for assistance in field work; to Dr. Mark Horn, International Consultant at Embrapa Recursos Genéticos e Biotecnologia, for English revision and comments for manuscript improvement; and to Conselho Nacional de Desenvolvimento Científico e Tecnológico and Fundação de Apoio à Pesquisa do Distrito Federal, for financial support.

\section{References}

ALDRICH, J.R. Chemical ecology of the Heteroptera. Annual Review of Entomology, v.33, p.211-238, 1988.

ALDRICH, J.R.; KHRIMIAN A.; CAMP, M.J. Methyl 2,4,6-decatrienoates attract stink bugs (Hemiptera: Heteroptera: Pentatomidae) and tachinid parasitoids. Journal of Chemical Ecology, v.33, p.801-815, 2007.

BORGES, M.; MORAES, M.C.B.; PEIXOTO, M.F.; PIRES, C.; SUJII, E.R.; LAUMANN, R.A. Monitoring the Neotropical brown stink bug Euschistus heros (F.) (Hemiptera: Pentatomidae) with pheromone-baited traps in soybean fields. Journal of Applied Entomology, v.135, p.68-80, 2011.

BORGES, M.; MORI, K.; COSTA, M.L.M.; SUJII, E.R. Behavioural evidence of methyl-2,6,10-trimethyltridecanoate as a sex pheromone of Euschistus heros (Heteroptera: Pentatomidae). Journal of Applied Entomology, v.122, p.335-338, 1998a.

BORGES, M.; SCHMIDT, F.V.G.; SUJII, E.R.; MEDEIROS, M.A.; MORI, K.; ZARBIN, P.H.G.; FERREIRA, J.T.B. Field responses of stink bugs to the natural and synthetic pheromone of the Neotropical brown stink bug, Euschistus heros (Heteroptera: Pentatomidae). Physiological Entomology, v.23, p.202-207, 1998b.

CORREAA-FERREIRA, B.S.; MOSCARDI, F. Biological control of soybean stink bugs by inoculative releases of Trissolcus basalis. Entomologia Experimentalis et Applicata, v.79, p.1-7, 1996.

CULLEN, E.M.; ZALOM, F.G. Phenology-based field monitoring for consperse stink bug (Hemiptera: Pentatomidae) in processing tomatoes. Environmental Entomology, v.29, p.560-567, 2000.

CULLEN, E.M.; ZALOM, F.G. Relationship between Euschistus conspersus (Hem., Pentatomidade) pheromone trap catch and canopy samples in processing tomatoes. Journal of Applied Entomology, v.129, p.505-514, 2005.

ENDO, N.; WADA, T.; NISHIBA, Y.; SASAKI, R. Interspecific pheromone cross-attraction among soybean bugs (Heteroptera): does Piezodorus hybneri (Pentatomidae) utilize the pheromone of Riptortus clavatus (Alydidae) as a kairomone? Journal of Chemical Ecology, v.32, p.1605-1612, 2006.

FEHR, W.R.; CAVINES, C.E.; BURMOOD, D.T.; PENNINGTON, J.S. Stage of development descriptions for soybeans, Glycine max (L.) Merrill. Crop Science, v.11, p.929-931, 1971.

HAMMER, Ø.; HARPER, D.A.T.; RYAN, P.D. PAST: palaentological statistic software package for education and data analysis. Palaeontologia Electronica, v.4, p.1-9, 2001.

HERBERT, A.D.; HARPER, J.D. Modification of the shake cloth sampling technique for soybean insect research. Journal of Economic Entomology, v.76, p.667-670, 1983.

KHRIMIAN, A. The geometric isomers of methyl-2,4,6-decatrienoate, including pheromones of at least two species of stink bugs. Tetrahedron, v.61, p.3651-3657, 2005.

KHRIMIAN, A.; SHEARER, P.W.; ZHANG, A.; HAMILTON, G.C.; ALDRICH, J.R. Field trapping of the invasive brown marmorated stink bug, Halyomorpha halys (Stal), with geometric isomers of methyl 2,4,6-decatrienoate. Journal of Agriculture Food and Chemistry, v.56, p.197-203, 2008.

KOGAN, M.; PITRE JUNIOR, H.N. General sampling methods for above-ground populations of soybean arthropods. In: KOGAN, M.; HERZOG, D.C. (Ed.). Sampling methods in soybean entomology. New York: Springer-Verlag, 1980. p.30-60.

LEE, K.C.; KANG, C.H.; LEE, D.W.; LEE, S.M.; PARK, C. G.; CHOO, H.Y. Seasonal occurrence trends of Hemipteran bug pests monitored by mercury light and aggregation pheromone traps in sweet persimmon orchards. Korean Journal of Applied Entomology, v.41, p.233-238, 2002.

MALAGUIDO, A.B.; PANIZZI, A.R. Pentatomofauna associated with sunflower in Northern Paraná State, Brazil. Anais da Sociedade Entomológica do Brasil, v.27, p.473-475, 1998.

MCBRIEN, H.L.; MILLAR, J.G.; RICE, R.E.; MCELFRESH, J.S.; CULLEN, E.; ZALOM, F.G. Sex attractant pheromone of the red-shouldered stink bug Thyanta pallidovirens: a pheromone blend with multiple redundant components. Journal of Chemical Ecology, v.28, p.1797-1818, 2002.

MILLAR, J.G. Methyl (2E,4Z,6Z)-deca-2,4,6-trienoate, a thermally unstable, sex-specific compound from the stink bug Thyanta pallidovirens. Tetrahedron Letters, v.38, p.7971-7972, 1997.

MILLAR, J.G.; MCBRIEN, H.L.; HO, H.Y.; RICE, R.E.; CULLEN, E.; ZALOM, F.G.; UOKL, A. Pentatomid bug pheromone in IPM: possible applications and limitations. IOBC WPRS Bulletin, v.25, p.1-11, 2002.

MORAES, M.C.B.; MILLAR, J.G.; LAUMANN, R.A.; SUJII, E.R.; PIRES, C.S.S.; BORGES, M. Sex attractant pheromone from the neotropical red-shouldered stink bug, Thyanta perditor (F.). Journal of Chemical Ecology, v.31, p.1415-1427, 2005. 
PANIZZI, A.R.; HERZOG, D.C. Biology of Thyanta perditor (Hemiptera: Pentatomidae). Annals of the Entomological Society of America, v.77, p.646-650, 1984.

PANIZZI, A.R.; SLANSKY JUNIOR, F. Review of phytophagous pentatomids (Hemiptera: Pentatomidae) associated with soybean in the Americas. Florida Entomologist, v.68, p.184-214, 1985.

PANIZZI, A.R.; CORREAA-FERREIRA, B.S. Dynamics in the insect fauna adaptation to soybean in the tropics. Trends in Entomology, v.1, p.71-88, 1997.

PANIZZI, A.R.; MCPHERSON, J.E.; JAMES, D.G.; JAVAHERY, M.; MCPHERSON R. Stink bugs (Pentatomidae). In: SCHAEFER, C.W.; PANIZZI, A.R. (Ed.). Heteroptera of economic importance. Boca Raton: CRC, 2000. p.421-474.

PIRES, C.S.S.; SUJI, E.R.; SCHMIDT, F.G.V.; ZARBIN, P.H.G.; ALMEIDA, J.R.M.; BORGES, M. Potencial de uso de armadilhas iscadas com o feromônio sexual do percevejo marrom, Euschistus heros (Heteroptera: Pentatomidae), para o monitoramento populacional de percevejos praga da soja. Manejo Integrado de Plagas y Agroecología, v.7. p.70-77, 2006.

R DEVELOPMENT CORE TEAM. R: a language and environment for statistical computing. Vienna: R Foundation for Statistical
Computing, 2008. Available at: <http://www.R-project.org>. 2008. Aecessed on: 10 March 2010.

SUGIE, H.; YOSHIDA, M.; KAWASAKI, K.; NOGUCHI, H.; MORIYA, S.; TAKAGI, K.; FUKUDA, H.; FUJIIE, A.; YAMANAKA, M.; OHIRA, Y.; TSUTSUMI, T.; TSUDA, K.; FUKUMOTO, K.; YAMASHITA, M.; SUZUKI, H. Identification of the aggregation pheromone of the brown-winged green bug, Plautia stali Scott (Heteroptera: Pentatomidae). Applied Entomology and Zoology, v.31, p.427-431, 1996.

TADA, N.; YOSHIDA, M.; SATO, Y. Monitoring of forecasting for stink bugs in apple. 1. Characteristics of attraction to aggregation pheromone in Iwate Prefecture. Annual Report of the Society of Plant Protection of North Japan, v.52, p.224-226, 2001a.

TADA, N.; YOSHIDA, M.; SATO, Y. Monitoring of forecasting for stink bugs in apple. 2. The possibility of forecasting with aggregation pheromone. Annual Report of the Society of Plant Protection of North Japan, v.52, p.227-229, 2001 b.

WALDBAUER, G.P. Damage to soybean seeds by South American stink bugs. Anais da Sociedade Entomológica do Brasil, v.6, p.223-229, 1977.

Received on August 12, 2010 and accepted on January 15,2011 